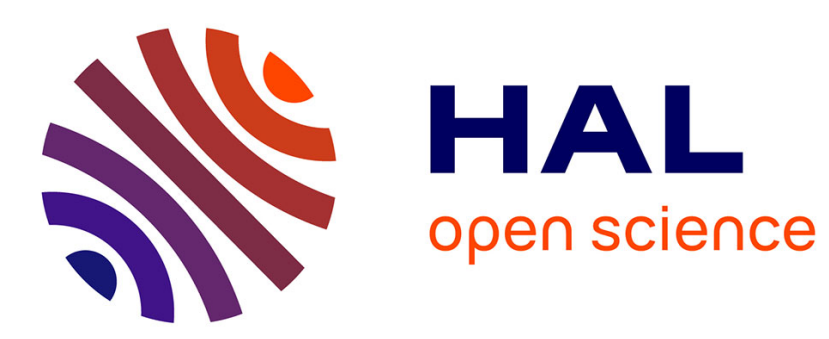

\title{
Language, Communication, and Socially Situated Cognition in Entrepreneurship
}

\author{
Jean Clarke, Joep P. Cornelissen
}

\section{To cite this version:}

Jean Clarke, Joep P. Cornelissen. Language, Communication, and Socially Situated Cognition in Entrepreneurship. Academy of Management Review, 2011, 36 (4), 776-778 p. hal-02276729

\section{HAL Id: hal-02276729 \\ https://hal.science/hal-02276729}

Submitted on 3 Sep 2019

HAL is a multi-disciplinary open access archive for the deposit and dissemination of scientific research documents, whether they are published or not. The documents may come from teaching and research institutions in France or abroad, or from public or private research centers.
L'archive ouverte pluridisciplinaire HAL, est destinée au dépôt et à la diffusion de documents scientifiques de niveau recherche, publiés ou non, émanant des établissements d'enseignement et de recherche français ou étrangers, des laboratoires publics ou privés. 
Mitchell, R. K., Smith, B., Seawright, K. W., \& Morse, E. A. 2000. Cross-cultural cognitions and the venture creation decision. Academy of Management Journal, 43: 974-993.

Nicolaou, N., Shane, S., Cherkas, L., Hunkin, J., \& Spector, T. D. 2008. Is the tendency to engage in entrepreneurship genetic? Management Science, 54: 167-179.

Ozgen, E., \& Baron, R. A. 2007. Social sources of information in opportunity recognition: Effects of mentors, industry networks, and professional forums. Journal of Business Venturing, 22: 174-192.

Sarasvathy, S. D. 2001. Causation and effectuation: Toward a theoretical shift from economic inevitability to entrepreneurial contingency. Academy of Management Review, 26: $243-288$.

Shepherd, D. A., \& Krueger, N. F. 2002. An intentions-based model of entrepreneurial teams' social cognition. Entrepreneurship Theory and Practice, 27: 167-185.

Smith, E. R., \& Semin, G. R. 2004. Socially situated cognition: Cognition in its social context. Advances in Experimental Social Psychology, 36: 53-117.

Taylor, J. R., \& Van Every, E. 2000. The emergent organization: Communication as its site and surface. Mahwah, NJ: Lawrence Erlbaum Associates.

West, G. P., III. 2007. Collective cognition: When entrepreneurial teams, not individuals, make decisions. Entrepreneurship Theory and Practice, 31: 77-102.

White, R. E., Thornhill, S., \& Hampson, E. 2007. A biosocial model of entrepreneurship: The combined effects of nurture and nature. Journal of Organizational Behavior, 28: 451-466.

Ronald K. Mitchell (ronald.mitchell@ttu.edu) Brandon Randolph-Seng (b.rondolph-seng@ttu.edu) Texas Tech University

J. Robert Mitchell (rmitchell@ivey.ca) University of Western Ontario

http://dx.doi.org/10.5465/amr.2011.0001

\section{Language, Communication, and Socially Situated Cognition in Entrepreneurship}

Mitchell, Randolph-Seng, and Mitchell start their commentary on our article by critiquing traditional models of cognition and information processing as offering up largely static theories and accounts of "abstract, disembodied cognitive structures" (p. 774). They hint at the growing body of work on socially situated cognition and embodied cognitive science as a way of removing the shackles of such traditional models and conceiving of a new cognitive agenda in entrepreneurship. We support this turn; indeed, our article (Cornelissen \& Clarke, 2010) started from many of the same commitments as work on socially situated and embodied cognition (as highlighted by Mitchell et al.). And while we agree with the broad gist of this movement, we also feel that it is important to highlight the role of language and communication in this agenda. Specifically, we believe it is important to recognize the formative role of language in conceptualizing venture opportunities and in influencing stakeholders about the feasibility of a venture, rather than discounting its influence or reducing it to a secondary process or outcome in relation to supposedly more basic cognitive processes at the level of individuals or groups. We unfold this emphasis on two levels: (1) the dynamic and active interrelation between language and thought, labeled sensemaking, and (2) the important role of language as a key mediating mechanism or device in influencing the cognitions of others, including, say, investors and other prospective stakeholders of a venture.

\section{SENSEMAKING, OR THINKING-FOR-SPEAKING}

A starting point for our article was the importance of embedding entrepreneurs in a social context and recognizing the role of that social environment in creating and justifying opportunities for ventures. Consistent with this approach, we argued that "while the inner thoughts and imaginations of entrepreneurs matter, they are not spoken or even necessarily speakable," and we should therefore direct our gaze, as researchers, to "the point where... ideas take form in the stream of the entrepreneur's experience, with external speech reconfiguring ideas to fit the demands of spoken language" (Cornelissen \& Clarke, 2010: 542). The linguist Slobin (1996) colls this "thinking-forspeaking," which refers to how individuals organize their thinking to meet the demands of linguistic encoding on line, during acts of speaking with others. As he notes, "Whatever else language may do in human thought and action, it surely directs us to attend-while speaking - to the dimensions of experience that are enshrined in grammatical categories" (1996: 71). Within this process, thought and language are intimately and dynamically connected at the point where individuals verbalize their 
ideas and, while communicating, articulate them in their speech to others.

Analogies and metaphors also demonstrate this dynamic relationship between language and thought; as inductive forms of reasoning, they are present in language and often characterized as figures of speech, but equally and simultaneously such language reflects cognitive modes of associative thinking and inferencing that may provide the core conceptual idea for a venture. One important consequence of this interrelation is that although basic perceptions and thoughts of entrepreneurs may exist outside of language, there is also overwhelming evidence that language use is formative in scoping and articulating an incipient idea (e.g., see Pinker, 2010). Grammatical language provides, in essence, a tool, both linguistically and cognitively, to pair, rearrange, and recombine words and grammatical constructions. Given that words and grammatical constructions will reference certain basic cognitive categories (e.g., objects, motion, causation, agency, etc.), such pairings and combinations may, as we have argued, present a novel conceptual image or representation of a venture opportunity (Cornelissen \& Clarke, 2010). One of the recent insights of the embodied cognition framework cited by Mitchell and colleagues is indeed that bodily action (including verbal speech) does not simply express previously formed mental concepts (Cornelissen \& Clarke, 2010); bodily practices, including language, social interaction, and gesturing, are part and parcel of the very activity in which concepts and conceptualizations are formed (e.g., Cornelissen, Clarke, \& Cienki, in press; Gibbs, 2006).

\section{SENSEMAKING AND COMMUNICATION}

Another point that we highlighted in our article is that speech, as part of communication in context, presents an important mediating mechanism between individuals, specifically in terms of how they understand each other's intentions as a situation unfolds. In contexts of communication and social interaction, individuals need to be able to model each other's evolving and contingent intentions and goals based on perceptible cues, but also primarily by attending to one another's communicative actions and displays (e.g., Sperber \& Wilson, 1995). Because we cannot read each other's minds directly, this means that "no mind can influence another except via mediating structure" (Hutchins \& Hazlehurst, 1995: 4). Externalized speech, once spoken, features as an important mediating mechanism in that it allows individuals to attribute intentions and thoughts to one another, without actually being privy to what someone is effectively thinking. Again, analogies and metaphors play a useful role here in that they encode and articulate novel ideas that entrepreneurs may have in terms of words and larger frames that, when well chosen, are already largely familiar to listeners or recipients (Cornelissen \& Clarke, 2010).

A further important point here is that individuals, while communicating, do not need to share or even have access to the same knowledge about the venture. Instead, in ongoing processes of communication, individuals generally exploit the built-up "common ground" between them as a resource for understanding and for deriving pragmatic inferences (Clark, 1996). As we suggested in our article, when an entrepreneur gets feedback from stakeholders who display whether they understand and accept the intentions for the venture, it allows the entrepreneur to validate that understanding or to correct it, and this, in turn, has consequences for the way in which the understanding of the venture evolves. One consequence of this is that the conceptual pacts that are agreed on by entrepreneurs and stakeholders, such as seeing the culture of a novel venture as a family (Baker, Miner, \& Eesley, 2003), have a strong claim on mutual understanding and any subsequent interactions.

We therefore agree with Mitchell and colleagues that there is value in focusing on the situated communication context and the way in which it affects individual and joint understanding about a venture. But this implies, in our view, a concomitant focus on language and communication-based mechanisms that actually enable and support the creation of individual and joint understanding. In fact, centering on the role of language and communication and its interdependencies with individual and group cognition is one of the fundamental aspects of current psychological and psycholinguistic research on socially situated and embodied cognition (e.g., Gibbs, 2006; Pinker, 2010). Thus, when we erect and advance this agenda in the 
entrepreneurship field, we would miss a real opportunity if we did not recognize one of its most fundamental and promising lines of inquiry.

\section{REFERENCES}

Baker, T., Miner, A. S., \& Eesley, D. T. 2003. Improvising firms: Bricolage, account giving and improvisational competencies in the founding process. Research Policy, 32: 255-276.

Clark, H. H. 1996. Using language. Cambridge: Cambridge University Press.

Cornelissen, J., \& Clarke, J. 2010. Imagining and rationalizing opportunities: Inductive reasoning and the creation and justification of new ventures. Academy of Management Review, 35: 539-557.

Cornelissen, J., Clarke, J., \& Cienki, A. In press. Sensegiving in entrepreneurial contexts: The use of metaphors in speech and gesture to gain and sustain support for novel ventures. International Small Business Journal.

Gibbs, R. W., Jr. 2006. Embodiment and cognitive science. Cambridge: Cambridge University Press.
Hutchins, E., \& Hazlehurst, B. 1995. How to invent a shared lexicon: The emergence of shared form-meaning mappings in interaction. In E. Goody (Ed.), Social intelligence and interaction: Expressions and implications of the social bias in human intelligence: 53-67. Cambridge: Cambridge University Press.

Pinker, S. 2010. The cognitive niche: Coevolution of intelligence, sociality, and language. Proceedings of the $\mathrm{Na}$ tional Academy of Sciences of the USA, 107: 8993-8999.

Slobin, D. 1996. From "thought and language" to "thinking for speaking." In J. J. Gumperz \& S. C. Levinson (Eds.), Rethinking linguistic relativity: 70-96. Cambridge: Cambridge University Press.

Sperber, D., \& Wilson, D. 1995. Relevance: Communication and cognition (2nd ed.). Oxford: Blackwell.

Jean Clarke (J.S.Clarke@lubs.leeds.ac.uk) University of Leeds

Joep Cornelissen (jcornelissen@feweb.vu.nl) VU University Amsterdam

http://dx.doi.org/10.5465/amr.2011.0192 
Copyright of Academy of Management Review is the property of Academy of Management and its content may not be copied or emailed to multiple sites or posted to a listserv without the copyright holder's express written permission. However, users may print, download, or email articles for individual use. 